\title{
DIVATRÓL ALKOTOTT VÉLEMÉNY A DIVAT SZAKMÁBAN, ILLETVE A NEM DIVAT SZAKMÁBAN DOLGOZÓK KÖRÉBEN
}

\author{
Csipkés Margit - Jávor János
}

\begin{abstract}
Absztrakt: Kutatásunk témájának egy olyan jelenséget választottunk, ami mindennapi életünkben jelentkezik, állandó körforgásban van, egyre nagyobb mértékben hozzájárul a gazdasági fejlödéshez, viszont elég keveset foglalkoznak vele. Ez a jelenség pedig nem más, mint a divat. Legföbb célkitüzésünk az volt, hogy párhuzamot állítsunk a divatvilágban dolgozók és nem divatvilágban dolgozók között. Kíváncsiak voltunk a vásárlási szokásaikra, illetve arra, hogy a két csoport hogyan vélekedik a feltett kérdéseinkre. Ezen kutatással szeretnénk rávilágítottam a téma komplexitására, illetve arra, hogy a marketing mellett még rengeteg tudományág foglalkozik a divat témakörével. Kutatási munkánk jelentőségét tïkrözi, hogy Magyarországon igen kevés figyelmet fordítanak a témával kapcsolatos megfigyelésekre, miközben egyre jobban behálózza életünket és a gazdaságot egyaránt. Kutatásunk elkezdése során is láttuk már, hogy a divatjavak fogyasztásának esetében sokféle befolyásoló hatást kell figyelembe venni.
\end{abstract}

\begin{abstract}
We have chosen a phenomenon of our research that is present in our everyday life, it is constantly circulating, contributes more to economic development, but it deals with little of it. This phenomenon is nothing but fashion. Our main objective was to make a parallel between those who work in the fashion world and those who are not in fashion. We were curious about their shopping habits and how the two groups think about our questions. With this research, I would like to highlight the complexity of the topic and the fact that besides marketing there are still a lot of disciplines dealing with fashion. Research work reflecting the importance of that in Hungary, very little attention is paid to the topics related to observations, while more and more enmeshed lives and the economy alike. Our research started during we have seen that the fashion consumption in the case of many kinds of influence must be taken into account.
\end{abstract}

Kulcsszavak: vásárlási szokás, divat, márka, kérdőívezés, ruházat

Keywords: purchase custom, fashion, brand, questionnaires, raiment

\section{Bevezetés}

Kutatásunk témájaként egy napjainkban igen gyorsan változó, állandó körforgásban lévő jelenséget, a divatot helyeztuik a középpontba. Kutatásunkban azt vizsgáltuk meg, hogy a vásárlási szokások hogyan alakulnak a divatvilágban, illetve a nem divatvilágban dolgozók esetében. A divat egyre nagyobb szerepet játszik mindennapi életünkben és egyre nagyobb piaci rétegeket hódít meg, emellett nagy mértékben hozzájárul a gazdaság fejlődéséhez. Valamiért azonban mégis csak kevesen foglalkoznak ezzel az igen meghatározó központi témával és a magyarországi szakirodalom is viszonylag kevés információval szolgál róla. Fontosságát, illetve esedékességét mutatja, hogy nem csak egyetlen tudományág, hanem többek között a szociológia, a szociálpszichológia, a pszichológia, a közgazdaságtan és természetesen a marketing is keresi a választ az ezekkel kapcsolatosan felmerülö kérdésekre. A téma jobb értelmezése érdekében kérdöíves felmérést végeztünk, melynek elemzését a cikkben helyeztük el. 


\section{Szakirodalmi áttekintés}

\subsection{A divat fogalmának meghatározása}

A divat fogalmát eddig viszonylag kevesen definiálták a divatot kutató, illetve ezzel a szakterülettel foglalkozó szakemberek közül. Az újabb kutatások szerint a divatnak egzakt, általánosan elfogadott meghatározása nem létezik. Ezért sokféleképpen értelmezik bonyolult jellegéböl adódóan. A fogalom meghatározásának változása a következöképpen figyelhető meg kronologikus sorrendben: 1938-ban Nystrom úgy fogalmaz, hogy a divat se nem több, se nem kevesebb, mint egy adott időszak uralkodó stílusa. Daniels 1951-es definíciója szerint a divat az, ami jelenleg helyénvaló. Robinson divaton a következőt érti: az újdonság önmagáért való hajszolása.

Az első komplex megfogalmazás 1979-ből, Sprolestől ered, ami így hangzik: „olyan magatartásmód, amelyet egy társadalmi csoport tagjainak megkülönböztethetö hányada átmenetileg átvesz, mert azt a választott magatartást társadalminak megfelelőnek tekintik az adott időre és helyzetre. A ma is érvényben lévő megfogalmazást 2006-ban definiálta az Amerikai Marketing Szövetség: a divat egy elfogadott és népszerü stílus (Kovács, 2009).

A számunkra a legjobban a divatot bemutató fogalom a következő volt: „divatnak nevezzük tágabb értelemben az egy-egy korszakra érvényes, és akkor általánosan elfogadott nézeteket a kultúra külső megjelenési formáiról, az életstílusról, az étkezési szokásokról, vagy az autókról éppúgy, mint a ruházkodásról. Szükebb értelemben a divat szón, ami mindezeknek a megjelenési formáknak az állandó, racionálisan soha teljesen meg nem magyarázható változékonyságát is jelenti, az öltözködést értjük (Kybalová et al., 1974: 15)."

A divattermékeket egyrészt a gazdasági szféra hozza létre és a termékeit piacra is viszi. Másrészt a divat állandó mozgásban is tartja a gazdaságot, mivel mindig az aktuális trendeknek kell megfelelnie. Elmondhatjuk, hogy e tényező mellett még társadalmi és kulturális szférában is megjelenik. A társadalmi termékek lehetnek a magatartásformák, ideológiák, filozófiák. A kulturális tényező lehet például a hajviselet, a szakállforma, az udvari környezet képe, vagy akár a belsőépítészeti megoldások. De ide tartozik még a keresztnév választás, az életszemlélet, a szabadidő eltöltése, tudományos módszerek, témák, beszédfordulatok is (Kovács, 2009).

Megismertük tehát, hogy a divat milyen színes és szerteágazó fogalom, ami jelen van mindennapi életünkben. Azonban a következőkben csak az öltözködésre fogunk fókuszálni, mert ez sokkal több annál, mint szabályok követése.

\subsection{A divat és stílus kapcsolata}

A divat és stílus szoros kapcsolatban áll egymással. Coco Chanel következő állítása is ezt tükrözi: „A divat változik, a stílus örök”. A saját stílusunk megalkotása nem más, mint egy önismereti út. Saját magunk tudjuk eldönteni (kialakítani), hogy kik vagyunk, milyen ruhadarabokban érezzük jól magunkat, illetve mit akarunk kifejezni öltözködésünkkel. 
A stílus egy olyan kifejezésmód, mely örökös körforgásban van. Tehát ha valami egyszer megjelenik, betör a divatba, az akár több generáción keresztül is fennmaradhat, majd érdektelenné válik és kimegy a divatból.

A divat és stílus kapcsolatát az 1. táblázat felsorolásból lehet a legegyszerübben megérteni. Ezen állítások alapján elmondható, hogy a divat és stílus szoros kapcsolatban van egymással, de mégis felfedi a kettő közötti ellentéteket. Rávilágít arra, hogy öltözködésünkkel valójában a külvilággal kommunikálunk. Az emberek elöbb kategorizálnak minket a megjelenésünk alapján, minthogy üdvözölnénk egymást. Tehát viseletünk adja vázát az első benyomásnak.

\section{5. táblázat: Divat és a stílus kapcsolata}

\begin{tabular}{|c|c|}
\hline \multicolumn{2}{|c|}{ A DIVAT } \\
\hline $\begin{array}{l}\text { ruhákról szól, a stílus a ruha } \\
\text { viselöjéről. }\end{array}$ & divat komoly, a stílus ironikus. \\
\hline $\begin{array}{llr}\begin{array}{l}\text { meghökkent, } \\
\text { gyönyörködtet. }\end{array} & \text { a stílus } \\
\end{array}$ & utánozható, a divat utánozhatatlan. \\
\hline divat változik, a stílus fejlődik. & olyan, mint egy kiegészítő, a stílus \\
\hline az anyag, a stílus a lényeg. & maga a jellem. \\
\hline öntudatos, a stílus magabiztos. & betủ szerint való, a stílus mindig eredeti \\
\hline rabszolgaság, a stílus hatalom. & _ merev, a stílus spontán. \\
\hline \multicolumn{2}{|c|}{ A divatot kívülröl határozzák meg, a stílus belülröl fakad. } \\
\hline A divatban az ár $\mathrm{f}$ & tos, a stílusban az érték. \\
\hline
\end{tabular}

Forrás: Saját összeállítás Molnár (2017) alapján

\subsection{A divat és a márka kapcsolata}

Mindennapjaink részévé váltak a márkák, egyre jelentősebb szerepet játszanak a márkázott termékek, egy-egy termékcsoport forgalmában. A marketing történetének korábbi éveiben a megkülönböztető szerep csak a származás helyével volt (Bauer et al., 2007). A fogyasztói társadalomban a vásárlás megkönnyítésére, a döntések befolyásolására, a reklámozott termékek azonosítására, a termékeknek olyan jeleknek és tulajdonságokkal kell rendelkeznie, amelyek megkülönböztetik a konkurenciától. Ez lett a marketing- és reklámszakemberek kiemelkedő feladata. Fontos meghatároznunk tehát a márka fogalmát: "A márka egy névhez, jelhez, formához, színhez, illetve ezek kombinációjához, valamint a terméktulajdonságokhoz kapcsolt asszociációk összessége. Alkalmas a termék azonosítására, a konkurenstől való megkülönböztetésére."

A divat és a márka kapcsolatának bemutatásához az egyes márka fajtákkal is tisztában kell lenünk. Legismertebb a termelői márka, amelyben a termék előállítója látja el jelzésével az árut. Az egyik a kereskedelmi márka nagy kereskedelmi áruházláncokhoz köthetö. A generikus márka az árfekvésével versenyzik. A másik a licenszmárka, mely nagyon érdekes, hiszen egy jól bevált márkát egy másik vállalat használatra megvásárol, így hozza forgalomba saját termékeit (a nagy divatcégek 
parfümjeit legtöbbször háztartási vegyipari cégek gyártják, terítik) (FazekasHarsányi, 2011).

A márkák a legkülönfélébb formában és méretben vannak jelen, lehetnek drágák vagy olcsók, megfoghatatlanok vagy tapinthatóak, illetve globálisak vagy nemzetiek. A legtöbb esetben egy márkánál a lényeg, hogy milyenek, mit képviselnek és mi teszi öket hatalmassá. Napjainkban az egyik legnagyobb és leghíresebb luxusmárka a piacon a francia LVMH, ami a Louis Vuitton, Möet \& Chandon és a Henessy összefogásával jött létre 1987-ben. Az LVMH egyszerre képvisel cigarettát, konyakot, pezsgőt, parfümöt, ékszereket és ruházati darabokat is. Luxusmárkák tömkelegét tudhatja magáénak világszerte. Ide tartozik például a Dior, Kenzo, Givenchy, Bulgari, Hublot, Tag Heuer, Don Perignon és a leghíresebb divatház is, a Louis Vuitton (Olins, 2004).

\subsection{A márkák fontossága a vevők életében}

Be kell lássuk, hogy a márkázás egy vállalat számára nagyon költséges dolog, mert magában foglalja az arculattervezést, annak alkalmazását, komplex márkakép kialakítását, fenntartását. Ez a befektetés azonban akkor térül meg, ha egy valóban sikeres márkát tudnak létrehozni, és menedzselni. A következő hasznos dolgokat hozhatja a jó márkanév a vállalat számára:

- A fogyasztó hajnaldó magasabb árat fizetni a márkás termékért.

- Egyfajta lojalitás alakul ki a vásárlóban, hiszen hajlandó akár nagy erőfeszítést is tenni vásárlása során kedvelt márkája megszerzéséért.

- Az úgynevezett fogyasztói szájreklám és az általános ismertségnek köszönhetően egyre kevesebb pénzt kell fordítani a népszerüsítésre.

- Nagyobb bizalomra számíthat.

- A versenytárs nem tudja utánozni az adott terméket, illetve a szolgáltatásokat.

Összefoglalva tehát a márka valóban egy érték, mert elég csak arra gondolnunk, hogy a vásárló egy pohár vízért hajlandó több száz forintot fizetni, ha az egy márkás ásványvíz, vagy oxigénmentes víz, netán lúgosító víz. Lássuk be, ezekről a többlettartalmakról csak a márkába vetett hit biztosítja öt (Rekettye et al., 2015).

$\mathrm{Az}$ elmúlt néhány évtizedben a különböző divatmárkák, az olcsó árkategóriájú boltoktól a luxus áruházakig hatalmas globális üzletté nőtték ki magukat. Ezt mutatja az 1. ábra is. Az első három helyezett között nagy különbségek vannak. Látható, hogy 2015. évben a legértékesebb divatmárka a Louis Vuitton, ami a luxus kategóriát képviseli és 22,55 milliárd amerikai dollárt ér. A második a svéd fast fashion cég (H\&M), aki 21,08 milliárd amerikai dollárral van jelen. Emellett a harmadik legértékesebb a sportszergyártó Nike cég, amely csak kicsivel marad le az élmezőnyből a 19,86 milliárd amerikai dollárjával. A 10 márka együttes értéke 121,74 millió dollár volt 2015. évben. Az első három cég együttes értéke 63,49 milliárd amerikai dollár. Ök hárman a 10 legértékesebb divatmárka összértékének több mint felét teszik ki. 


\section{1. ábra: A világ 10 legértékesebb divatmárkája 2015. évben}

milliárd \$

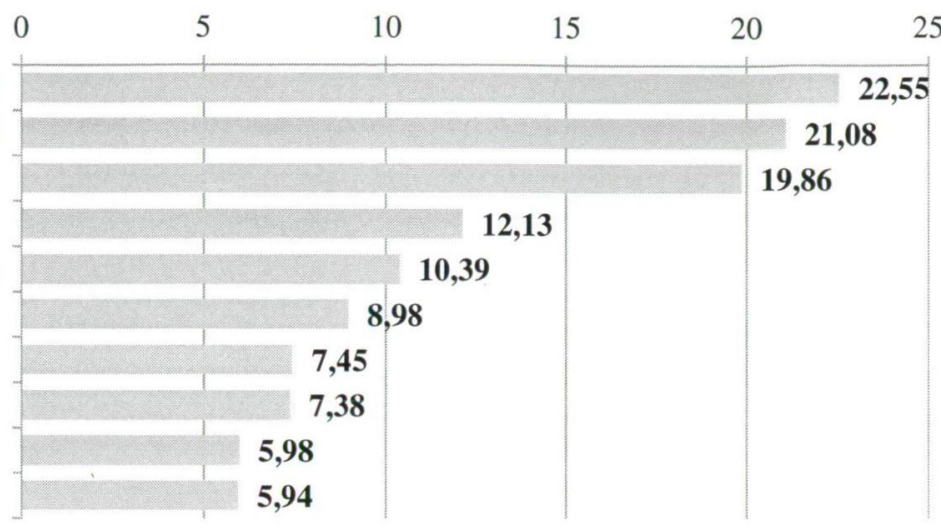

Forrás:Saját szerkesztés a Business Insider (2015) alapján

\section{5. Értékesítési csatornák a ruhakereskedelemben}

Miután ismertettem a ruházati piac jelenlegi helyzetét fontosnak tartom bemutatni, hogy hol is vásárolhatjuk meg azokat. Véleményem szerint a kiskereskedelmi formák azok, melyekben legjellemzőbbek a ruházati termékek árusítása és vásárlása.

A Központi Statisztikai Hivatal 2016. júniusi adatai szerint 16630 darab ruházati, 2888 lábbeli- és bỏráru, illetve 2076 óra-, és ékszerüzlet volt Magyarországon. Ezek a teljes belföldi eladási forgalom 7,06 százalékát tették ki, ami 147885 millió forintot jelent (KSH, 2016).

\section{2. ábra: Az egy före jutó havi kiadások megoszlása százalékban kifejezve,} 2016 I. félév

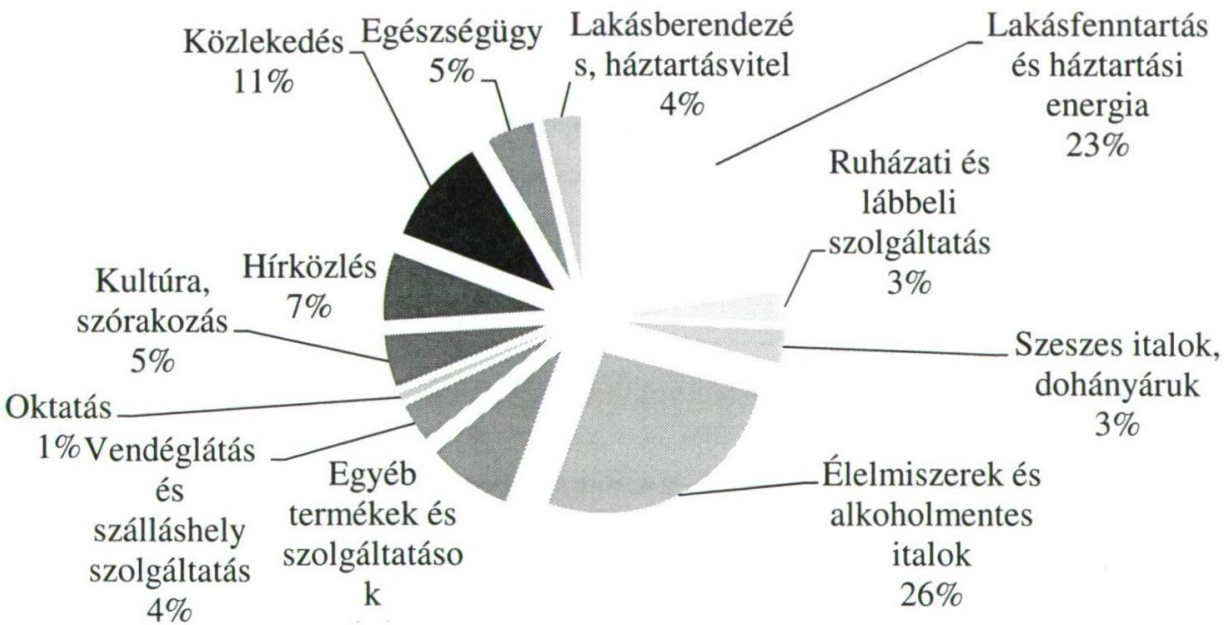

Forrás: KSH (2016) 
A KSH 2016-os közleményéböl az is kiderül, hogy az első félévben a magyar lakosságnak 74400 forint az egy före jutó átlagos kiadása. Emellett a 2016-os év első félévében 2230 forint volt a magyar lakosság egy före jutó havi fogyasztási kiadása ruházati cikkekre és lábbeli termékekre $(\mathrm{KSH}, 2016)$. A 2. ábra azt szemlélteti, hogy egy hónapban az egy före jutó havi megoszlások tekintetében egy fö átlagosan mire költ. A költségek felét az élelmiszer és alkoholmentesek italokra, illetve a lakásfenntartásra és háztartási energiára költjük Magyarországon. A ruházkodásra megközelítőleg 3\%-ot költünk havonta a fizetésünkből.

A vásárlási helyek, illetve a ruhaárusító helyek közül a következö 6 csoportot tartjuk fontosnak, melyek a kérdőivezésünk esetében is fontos cél volt, hiszen a vásárlási szokásoknál ezeket a helyeket jelölték meg a megkérdezettek nagyrészben: Bevásárlóközpontok: egy angol kifejezéssel lehet a legjobban leírni lényegét: everything is under one roof, azaz mindent egy fedél alatt van. A különböző profilú és méretű kereskedelmi egységeket boronálja össze. A vásárló mindent egy helyen megkap (termékeket, szolgáltatásokat, vendéglátóegységeket és szórakozási lehetöséget egyaránt). Kereteit általában egy ingatlanfejlesztő vagy beruházó cég hozza létre, aki bérbe adja az üzlethelységeket, vagy eladja a kiskerekedőknek. Ezek az épületek általában többszintesek és szintenként több folyosós. Általában minden bevásárlóközpontnak van legalább egy meghatározó, húzó üzlete az úgynevezett mágnesbérlő. Magyarország legnagyobb bevásárlóközpontjai a West End, az Aréna Pláza, az Árkád és a Fórum.

- Áruházak: ezek olyan kiskereskedelmi egységek, amelynek eladótere eléri legalább a 2500 négyzetmétert, az alkalmazottak száma pedig 175 fónél több, és legalább öt különböző részlege van (Rekettye et al., 2015). Széles körü kiszolgálást és széles választékot kínálnak a fogyasztóknak, sőt elég gyakori, hogy saját márkanévvel ellátott termékeket is forgalmaz. Napjainkban föleg ruházati és háztartási felszereleséseket forgalmazó áruházakkal találkozhatunk. Magyarországon nem jellemzö, hogy a ruházati termékeket áruházakban árusítsák, ezeknek a szerepét a bevásárlóközpontok vették át. Azonban meg kell említeni a Skálát, ami 18 áruházat foglal magában. Tölünk nyugatabbra viszont találunk világhírü áruházakat is (például: a Harrods Londonban, a Galeries Lafayette Párizsban, vagy a Barneys New Yorkban).

- Butikok: kisebb méretüek, egy termékcsoportból széles választékot, több márkát kínáló üzletek, vagy márkaboltok. Az eladószemélyzet magasan képzett, a vásárlók személyre szabott kiszolgálást is élvezhetnek a butikokba betérve (Vágási, 2007). Itt általában olyan termékek megvásárlására van lehetőség, melyeket máshonnan nem tudnánk beszerezni. Kellemesebb atmoszférát nyújtanak a bevásárlóközpontoknál, illetve kevesebb árucikk is található náluk, viszont az árak magasabbak. Szerencsére Magyarországon elég sok világmárka képviselteti magát, mint például Armani, Calvin Klein, Gucci, Polo by Ralph Lauren. 
Használtruha üzletek: ezeket két kategóriára sorolhatjuk, a minősági és a kevésbé minőségi használtruha üzletekre. A minőségi használtruha kereskedő alaposan megválogatja, hogy milyen áru kerül az üzletébe. Itt viszonylag drágább áron juthatunk hozzá a használt termékekhez, ám könnyen különleges és egyedi darabokra is akadhatunk. A kevésbé minőségi használtruha boltokban már nem figyelnek a minőségre, a ruhák úgynevezett bálákban érkeznek, viszont itt is könnyen márkás darabokat lelhetünk (Martin-Lehu, 2011). Magyarországon a legismertebb az Angex használtruha üzletlánc, illetve a Csóra, ami cipöket, kiegészítőket forgalmaz.

- Outletek, outlet centerek: olyan kereskedelmi egységek, amelyek a gyártó által vannak müködtetve. A kifutó, szezonját múlt vagy megmaradt termékeket árulják, a bolti árnál jelentősen olcsóbban. Akár 30-70 százalékos kedvezményre is szert tehetünk. Eredeti, jó minőségü, márkás termékek forgalmazásáról van tehát szó (Rekettye et al., 2015). Jó példa a polgári M3 Outlet, a Party22 Budapesten.

\subsection{Elektronikus kiskereskedelem}

Manapság az egyik legelterjedtebb formája a ruha vásárlására az interneten zajlik. $\mathrm{Az}$ elektronikus kereskedelem egy új értékesítési csatorna, amely az internet térhódításával alakult ki és piaci részesedése évről-évre növekszik. Ez annak is köszönhető, hogy földrajzi és időbeli körlátok nem gátolják a vásárlást. Az ekereskedők a világhálón értékesítik, kommunikálják az eladásra szánt termékeiket a fogyasztók felé, sok esetben személyre szabott ajánlatok formájában. Megállapíthatjuk tehát, hogy a bolti kiskereskedelem üzlettípusainak tökéletes mása, azaz virtuális változata az online kiskereskedelem. Az e-kereskedelem számos költséget megtakarít a vállalat számára, illetve megkönnyíti, kényelmesebbé teszi a vásárlásokat (Agárdi, 2010).

Az online vásárlás a ruhavásárlás azon formája, amikor a kirakat és az árukészlet teljes egésze megjelenik szemünk előtt a képernyőkön, így kényelmesen, otthonunkban válogathatunk a jobbnál jobb kínálatból. Ezeknek az igények kielégítésére megjelentek az úgynevezett webshopok, ahol az adott cég teljes termékpalettája jelen van. A Fast Fashion vállalatoktól kezdve a Haute Couture divatházakig alkalmazzák ezt az értékesítési csatornát. Ez azért is jó, mert olyan márkákat, ruhákat is meg tudunk így rendelni, amely nem rendelkezik Magyarországon fizikális bolttal. Az online ruhavásárlásnak is vannak előnyei és hátrányai természetesen. Előnyei például: kényelmes; nem kell sorban állni, cipekedni; nincs nyitvatartáshoz kötve; gyors; biztonságos; nagyobb választék. Hátrányai például: nem megfelelő méret rendelése esetén bonyolult visszatérítési folyamat; nem biztos, hogy azt a hatást kelti felvéve a termék, amit el szerettünk volna érni; a megrendelt termék nem érkezik meg időben, vagy meg sem érkezik; a termék megsérült, megrongálódott a szállítás során; nem megfelelö a termék minősége; nem tartózkodunk otthon, amikor a futár érkezik (Rekettye et.al, 2015). 


\section{Anyag és módszer}

A kutatási módszereket két kategóriára oszthatjuk fel. Az egyik a primer kutatás, ami első kézből származó információkat szolgáltat, míg a másik a típus a szekunder kutatás, amely másodkézből származó adatgyüjtési módot jelent. A választott témánk vizsgálata során mindkét kutatási módszert alkalmaztunk.

Mivel a primer adatok gyüjtésének előfeltétele a szekunder adatok gyüjtése és elemzése, ezért kutatásunkban a szekunder információgyüjtési módszert alkalmaztuk a szakirodalmunk elkészítéséhez. A másodlagos, szekunder adatgyüjtés lényege, hogy a már más által feldolgozott anyagokat a saját szempontunk szerint hasznosítsuk, tehát a hozott anyagból kell dolgozni. Az adatgyüjtés fontos módszere ez a fajta kutatási mód, amelynek során átvesszük mások adatait és eredményeit. Tulajdonképpen felfogható egy kreatív szakirodalmi kutatásnak is. A módszer alkalmazásának előnye, hogy a rendelkezésre álló adatokhoz könnyen, olcsón és gyorsan hozzá lehet férni. Hátrányai közé sorolható, hogy a leírt adatok nem feltétlenül pontosak, illetve hamar elavulhatnak, ezért a kutatási folyamat során nagy körültekintéssel kell ezeket vizsgálni. Ide sorolható még az a tényező is, hogy ezekhez az adatokhoz nem csak mi, hanem mások is hozzáférhetnek. A rendelkezésre álló adatok származhatnak belső vagy külső forrásokból is (Majoros, 2004).

A primer kutatás megvalósításának előfeltétele a jó szekunder kutatás, mivel fontos megismerni a tudományos szakemberek eredményeit, ahhoz, hogy el tudjuk különíteni saját eredményeinket az előzményektől. Az elsődleges, azaz a primer adatok azok az információk, amelyeket maga a kutató gyüjt és nem a korábban már publikált forrásból származik. Ide tartozik a különböző magánszemélyek, háztartások megkérdezéséből és megfigyeléséből származó adatok. Előnye, hogy az adott problémára, témakörre fókuszál, tehát nincs szükség a számunkra lényegtelen információk kiszürésére, valamint viszonylag pontos adatokkal szolgál. Hátránya, hogy elvégzésének költsége igen magas és az elkészítésének időtartalma hosszú időt vesz igénybe. A primer adatgyưjtés fö módszerei a kísérlet, a megfigyelés és a megkérdezés, ami a kérdőívezést illetve az interjút foglalja magában (Rédey, 1990).

Primer adatszerzésem folyamán a véleménykutatás egyik legtipikusabb eszközét, a kvantitatív kérdőívezés módszerét választottunk, ami a leggyakoribb kutatási, információszerzési technika. Ennek célja az volt, hogy információt gyüjtsek az emberek, illetve a népesség egy célcsoportjáról. Kutatómunkánk során a kvantitatív kérdőívezést online felületen végeztük. A kérdéssort Google által kifejlesztett Ürlapok nevü internetes szerkesztővel hoztuk létre, majd megosztottuk a Facebook közösségi oldalunkon. A több, mint százezer rajongóval rendelkező Glamour Online, ami a Glamour Magazin Facebook-os oldala szintén megosztottuk, így rengeteg emberhez jutott el az ürlapunk. A kitöltés teljes mértékben anonim és önkéntes módon, valamint véletlenszerüen zajlott. A kérdőívünk zárt kérdésekből álltak. A kérdőívet addig nem lehetett lezárni, míg az összes kérdésre nem válaszolt a megkérdezett, ezért az 556 beérkezett válaszból mind használható volt. Felmérésünk 19 kérdést tartalmazott, ezeket 4 témakörre bontottunk fel. 
Fontosnak tartottuk, hogy az első kérdéssel kiszürjük a divatvilágában, illetve a nem ott dolgozókat, mert eltérő a két csoport ízlésvilága. A kapott eredményeket a 3. ábra szemlélteti. Az összehasonlítások alapja a két csoport, a divatvilágban és a nem divatvilágban dolgozók. A kérdések megalkotásakor az elődleges szempont a vásárlási szokások vizsgálata volt, valamint kitértük az árakkal, minőséggel, márkákkal kapcsolatos tényezőkre is. Az utolsó kérdéskör a demográfiai változókat mérte fel. A kérdöívünk tartalmaz feleltválasztós kérdéseket, ahol kettő, vagy több lehetőség közül választhatták ki a válaszadók a számukra legjellemzőbb állításokat. Emellett skálás kérdéseket is tartalmazott a kérdőív, itt a kitöltők egytől ötig terjedő skálán tudták értékelni, mennyire jellemzőek az adott kérdések a kérdőívünkben. A kérdések egyetlen egy nyitott kérdést tartalmaznak, ez a kitöltők életkorára irányult. Ez azért volt, mert úgy gondoltuk, hogy így részletesebb eredményeket tudunk elérni.

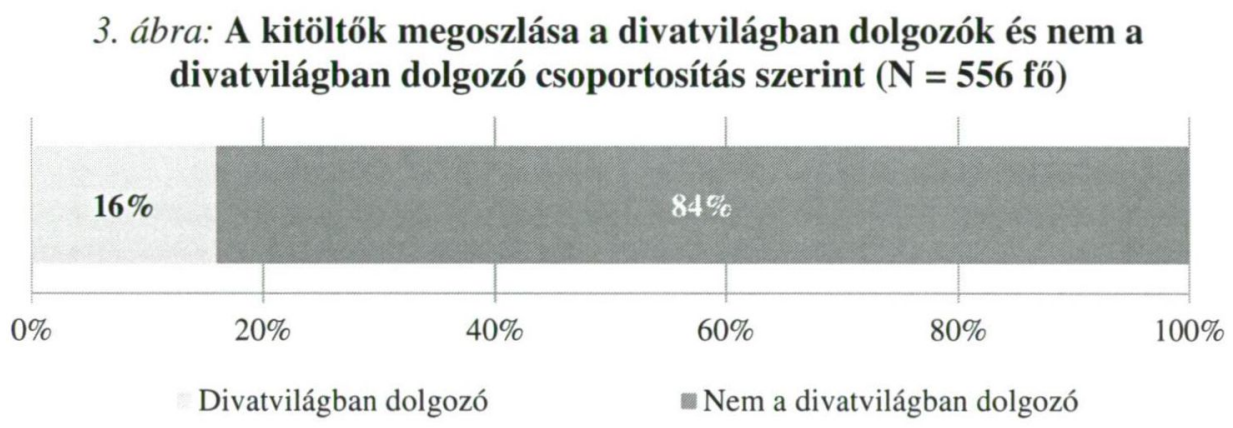

Forrás: Saját forrás (2017)

Kérdőívünket összesen 556 fő töltötte ki. A minta összetétele reprezentatív, mivel a kérdőívet a Facebook közösségi média oldalon osztottuk meg, illetve szakmai oldalon is megjelentettük, így bárki kitölthette. Vagyis a megkérdezett csoport összetétele nem tükrözi teljes mértékben a vizsgált sokaság összetételét, mivel a nemek aránya nem egyezik meg. A kitöltők csupán 10\%-a volt férfi, $90 \%$ pedig nő volt.

A kutatásunk alapján szerzett adatokat a Microsoft Excel táblázatkezelő programmal elemeztük ki, melynek segítségével átlag és szórás, gyakorisági megoszlásokat készítettünk.

\section{Eredmények és azok értékelése}

\section{1. Demográfiai adatok ismertetése}

$\mathrm{Az}$ értékelését a minta megismerésének céljából a demográfiai háttérváltozók ismertetésével kezdtük. Ebben a kérdéskörben felmértük a nemekkel, a korral kapcsolatos kérdéseket, illetve a válaszadók iskolai végzettségét és a lakóhelyüket, valamint az egyének jelenlegi jogi helyzetét és a KSH adatait alapul véve a havi bruttó jövedelmi megoszlásukat is. 
A kitöltők életkorát hat kategóriára osztottam fel, hiszen a skála igen széles volt a válaszokból (13 évestől 74 éves korig érkeztek be válaszok). A kor és nem szerinti megoszlások alakulását a 2. táblázatban szemléltetem. Ez alapján a hat korcsoport így alakul: 13-21 évesek, 22-31 évesek, 32-41 évesek, 42-52 évesek, 53-74 évesek. A korcsoportokat a divatvilágban dolgozó modellek életkora szerint határoztuk meg. Hasonlóságot vonhatunk a termékéletgörbe és a modellek karrierje között. Ez azt jelenti, hogy a bevezetés szakaszában egy kezdő modell 13-14 évesen kerül bele ebbe a világba Ekkor ismerkedik meg ezzel a világgal, illetve építi karrierjét. Ezután a 2231 korosztályban az addig felépített pályafutása a növekedés szakaszának tudható be. 32-41 éves korban következik be az érettség szakasza, majd a 42-52 éves korban a hanyatlás fedezhető fel. Manapság viszont az 53-74 éves korcsoportban levő modellek egyre inkább felkapottabbak, egyre több reklámban láthatjuk őket. Ezért ezt a korcsoportot a megújulás szakaszának nevezzuik.

Mint látható a legnagyobb szegmentumot a 22-31 év közötti nők alkotják, ami adódhat abból, hogy a választott témám, inkább a fiatal korosztályba tartozó nőket érdekli leginkább. Az 556 válaszadó közül, 554 föt sikerült kiértékeljünk, mivel 2 alany nem helyesen töltötte ki az életkorra vonatkozó kérdést (1. táblázat). A továbbiakban is 556 fővel elemeztük a kérdéseket, mivel nem az életkor megoszlásának szemléltetése volt a fö célunk a kutatás létrehozásakor.

\begin{tabular}{|c|c|c|c|c|c|c|}
\hline \multirow[b]{2}{*}{ Nemek } & \multicolumn{5}{|c|}{ Korcsoportok (fö) } & \multirow[b]{2}{*}{ Összesen } \\
\hline & 13-21 év & 22-31 év & 32-41 év & 42-52 év & 53-74 év & \\
\hline Nö & 133 & 223 & 74 & 42 & 24 & 496 \\
\hline Férfi & 14 & 30 & 8 & 3 & 3 & 58 \\
\hline Összesen & 147 & 253 & 82 & 45 & 27 & 554 \\
\hline
\end{tabular}

Forrás: Saját forrás (2017)

Kérdőívünk következő kérdésével felmértük a válaszadók iskolai végzettségét is. A kitöltők a következő 4 kategória közül választhattak: 8 általános vagy annál kevesebb, szakmunkásképző/szakiskola, szakközépiskola/gimnázium és felsőfokú végzettség. Ebből kiderült, hogy a legnagyobb csoportot a felsőfokú végzettséggel rendelkezők alkotják, akik a megkérdezettek majdnem felét jelentette. A második legnagyobb csoportot a szakközépiskolát, illetve gimnáziumot végzett, érettségivel rendelkezők alkotják, akik a megkérdeztettek közel 40\%-át fedték le. A további két kategóriám, a szakmunkásképző, szakiskolát végzettek, illetve a maximum 8 általános osztályt végzettek száma igen elenyésző.

A foglalkoztatásra vonatkozó kérdésünk válaszait a 4. ábra szemlélteti. Itt arra voltunk kíváncsiak, hogy mi a kitöltők jelenlegi jogi helyzete (fő tevékenységük). A minta majdnem felébe az aktív fizikai, illetve szellemi dolgozók tartoznak. Nagyjából a megkérdezettek egyharmadát a tanulók alkotják, míg a GYESesen/GYED-en levők 7,7\%-ban alkotják a sokaságot. Az egyéb inaktív keresők, a munkanélküliek, a nyugdíjasok és a háztartásbeliek $2 \%$ alatti részarányúak elenyésző. 


\section{4. ábra: A válaszadók jogi helyzete ( $\mathbf{N}=\mathbf{5 5 6}$ fö)}

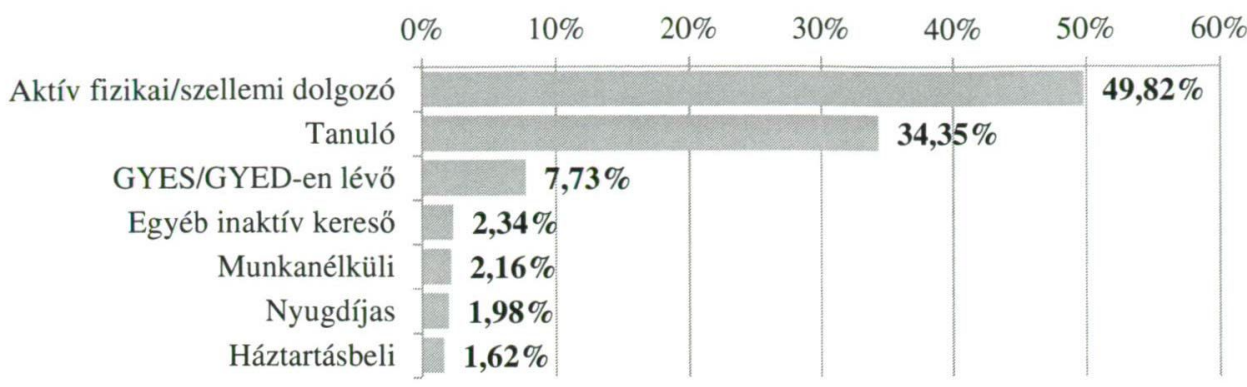

Forrás: Saját forrás (2017)

A következő kérdésünk az állandó lakóhelyre irányult (5. ábra). A válaszadók valamivel több, mint egyharmada városban, egyötöde fövárosban vagy megyei jogú városban él. A legkisebb csoportot a községben, faluban élők alkotják, részesedésük $13,4 \%$.

\section{5. ábra: A mintát alkotó egyének lakóhely szerinti megoszlása ( $\mathbf{N}=\mathbf{5 5 6}$ fö)}

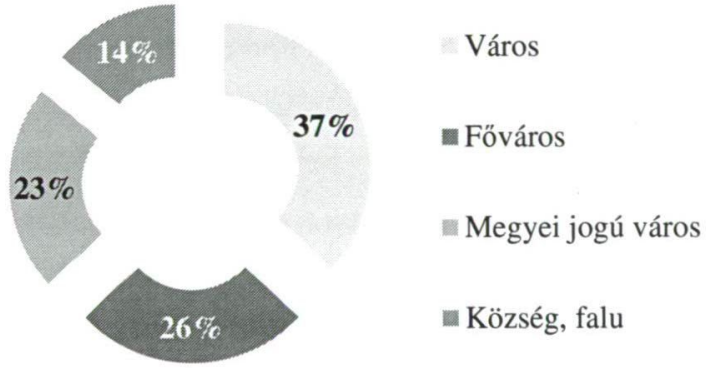

Forrás: Saját forrás (2017)

A demográfiai háttérváltozók vizsgálatának utolsó kérdése a kitöltők jelenlegi havi jövedelmi helyzetét kívánta feltárni. A KSH 2017. évi adatai szerint a havi bruttó átlagkereslet 303000 forint Magyarországon. Ez alapján 6 csoportot alakítottunk ki a keresetekre vonatkozó válaszok alapján, melyek a következők: jelentősen átlag feletti, átlag feletti, átlagos, átlag alatti, illetve jelentősen átlag alatti jövedelmủ személyek. A kitöltők valamivel kevesebb, mint egy ötöde vallotta, hogy nincs jövedelme.

\subsection{Ruhavásárlási szokások vizsgálata a megkérdezettek körében}

A vizsgálatban fö szempont volt az, hogy valaki divat világában, vagy a nem divat világában dolgozik-e, s így milyen véleménnyel van a feltett kérdésekre. A divatvilágban dolgozók 88 fővel, a nem divatvilágban dolgozók pedig 468 fővel vannak jelen a kiértékelésben.

$\mathrm{Az}$ első ruhavásárlási szokásokkal kapcsolatos kérdésnél arra voltunk kíváncsiak, hogy a kitöltők milyen rendszerességgel vásárolnak ruhákat. A kiértékelés után kiderült, hogy a divatvilágban dolgozók többsége, azaz 38,6\%-a 
havonta többször, illetve hetente is nagy számban vásároltak maguknak ruhákat. A nem divatvilágban dolgozók helyzete viszont másként alakult. Itt a beérkezett válaszok közel $40 \%$-a azt vallotta, hogy havonta vásárol. A havonta többször választ kevesebben, a válaszadók harmada jelölte be. A divatvilágában dolgozók csupán 2,3\%-a vásárol félévente egyszer, havonta ötöde, szezonálisan egyszer 3,4\%, naponta pedig senki nem vásárol közülük ruhákat. A nem divatvilágban dolgozók válaszadásának száma úgy alakul, hogy közel ötödük szezonálisan egyszer, félévente egyszer, hetente és naponta csak elenyészö számban vásárolnak ruhákat (6. ábra).

\section{6. ábra: A divatvilágban és nem divatvilágban dolgozók vásárlási rendszerességeik megoszlása $(\mathrm{N}=\mathbf{5 5 6}$ fö)}

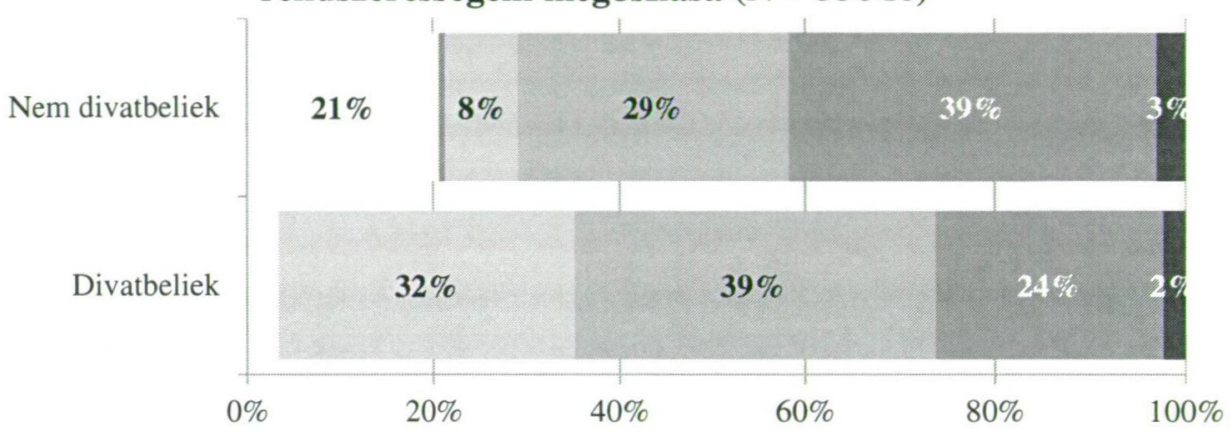

Szezonálisan egyszer $₫$ Naponta $₫$ Hetente $₫$ Havonta többször $₫$ Havonta $\mathbf{m}$ Félévente egyszer

Forrás: Saját forrás (2017)

A következő kérdésünkkel arra szerettünk volna választ kapni, hogy manapság az emberek hova járnak, illetve, hogy honnan szerzik be ruháikat. A válaszlehetőségeket a szakirodalmamban leírt bolti kiskereskedelmi formák alapján állítottuk össze. Ebben az esetben a megkérdezettek egyszerre több válaszlehetőséget is megjelölhettek, emiatt a százalékos értékek azt jelzik, hogy a minta összességének hány százaléka választotta az egyes lehetőségeket.

A beérkezett válaszok kiértékelése után a következő következtetések vonhatók le. Mindkét csoport kimagaslóan a bevásárlóközpontokban vásárolnak maguknak ruhákat, a divatvilágban dolgozók majdnem 90\%-a, míg a nem divatvilágban dolgozók több, mint háromnegyede választja ezt. A legnagyobb eltérést az internetes vásárlások megoszlása mutatja. Ez abból is eredhet, hogy aki nem a divatvilágban dolgozik, nincs teljesen tisztában a kínált termékekkel, anyagaikkal, méreteikkel, így ők inkább a fizikális boltokban szeretik megtapintani, felpróbálni, megvásárolni a ruháikat. Míg a divatvilágban dolgozók közel $60 \%$-a, addig a nem divatvilágban dolgozók kevesebb, mint fele vallotta azt, hogy interneten szerzi be öltözetét ( 7 . ábra).

Fontosnak tartottuk megvizsgálni még, hogy az emberek általában mennyi időt szánnak ruhavásárlásra. Ebből kiderült, hogy a divatvilágban dolgozók és a nem divatszakmában levők is 31-60 percet töltenek ruha-vásárlással egy alkalommal. A 
8. ábrából kiderül, hogy a divatvilágban dolgozók hosszabb időt töltenek el vásárlással, mint aki nem ebben a szakmában tevékenykedik. Látható, hogy a divatvilágban dolgozók fél és két óra közötti intervallumban szerzik be a számukra szükséges ruhadarabokat. Ez abból adódhat, hogy ők jobban szemügyre veszik az adott bolt teljes kínálatát, mivel számukra nagyon fontos a divatos megjelenés és ez több időt vesz igénybe.

\section{7. ábra: A divatvilágban és a nem divatvilágban dolgozók vásárlásának helye} $(\mathbf{N}=\mathbf{5 5 6}$ fö $)$

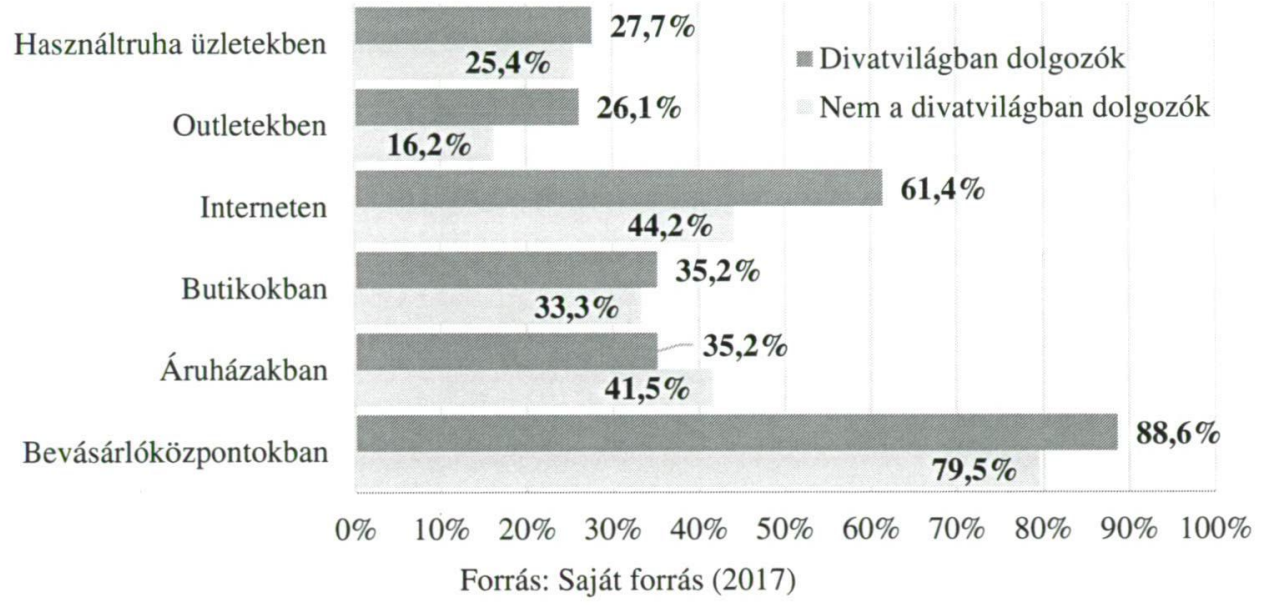

\section{8. ábra: A vásárlásra szánt időtöltés $(\mathbf{N}=\mathbf{5 5 6}$ fö)}

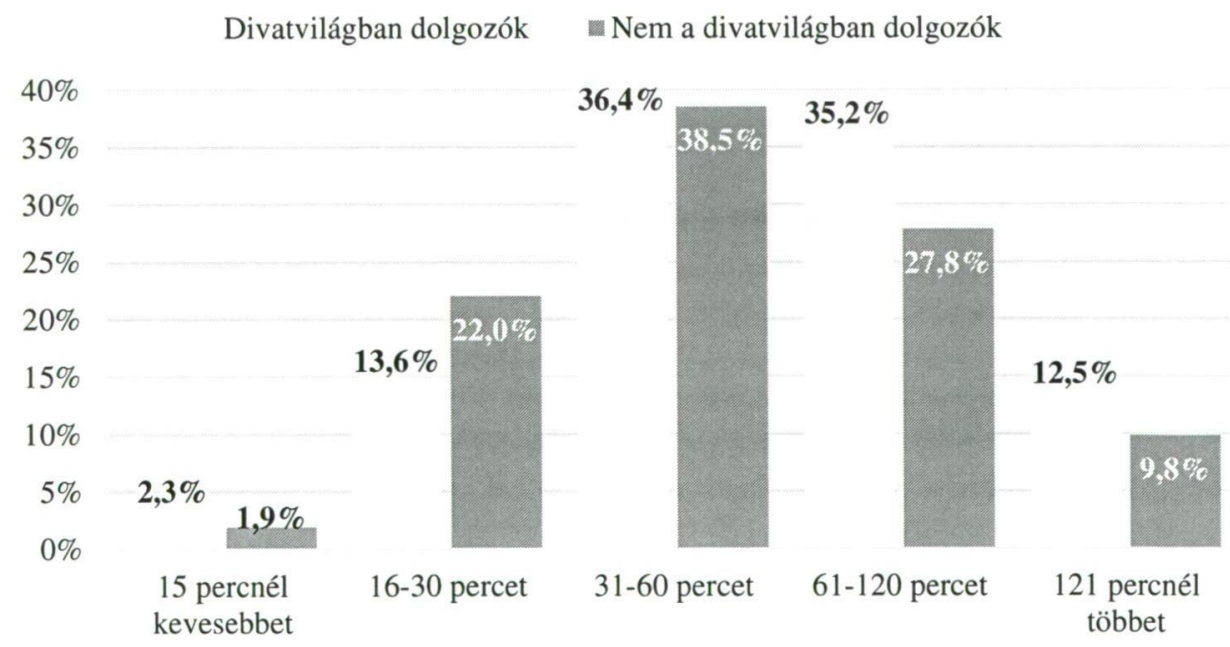

Forrás: Saját forrás (2017)

A válaszokból arra is kerestük a választ, hogy a kitöltők egy vásárlás alkalmával mennyit költenek öltözködésre. A 9. ábra megmutatja, hogy elég nagy eltérés van a 
két kitöltői réteg válaszait tekintve. Elmondható, hogy a divatvilágban dolgozók 35\%-a egy vásárlás alkalmával 10001-20001 forint közötti sávban költenek, míg a nem divatbeliek közel fele, pedig 5001-10000 forintot szánnak egy vásárlás alkalmával ruházkodásra. A másik érdekesség, hogy a divatban dolgozók majdnem ötöde, 20001 és 30000 forint között költ, míg a nem divatbeliek csupán tizede szán ennyi pénzt rá. Ezek a különbségek abból adódhatnak, hogy egy divatosabb, márkásabb ruha beszerzése nagyobb költségekkel járnak, mint egy kevésbé ismert, vagy márkajelzés nélküli termék. Nem elhanyagolható, hogy a divatvilágban dolgozóknak nagyobb hangsúlyt kell fektetni a külsejükre, így ruházkodásukra is, mivel nekik minden nap úgy kell kimenniük az utcára, mintha a kifutón lennének.

\section{9. ábra: Az egy vásárlás alkalmával elköltött pénzösszeg ( $\mathbf{N}=556$ fö)}

Divat világban dolgozó

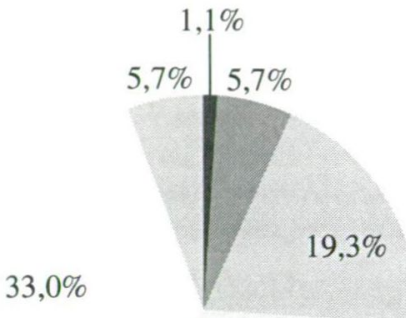

$35,2 \%$
Nem divat világban dolgozó

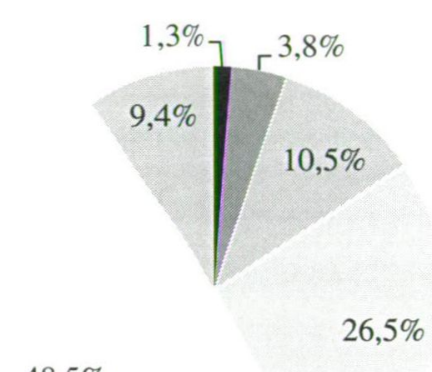

$48,5 \%$

5-10 ezer Ft

5 ezer Ft alatt

Forrás: Saját forrás (2017)

Fontos elemezni azt is, hogy a havi kiadás tekintetében hogyan oszlik meg a divatvilágban és nem a divatvilágban dolgozók költési sajátságai. A KSH adatai szerint a 2016-os év első felében 2230 forint volt a magyar lakosság egy főre jutó havi fogyasztási kiadása ruházati cikkekre és lábbeli termékekre (KSH, 2016). A 10. ábráról leolvasható, hogy ez az állítás nem igazán állja meg a helyét, mivel a megkérdezettek körében, legnagyobb arányban, azaz $22 \%$ és $32 \%$-ban azt vallotta, hogy 5001-10000 forint között költenek havonta.

A divatvilágban dolgozók között nem ritka, hogy 50001 forint felett adnak ki egy hónapban ruházkodásra, ezzel ellentátben a nem divatvilágban dolgozók csupán 3\%-a költ ennyit. A kevesebb, mint 5000 forintot költök között is nagy eltérés van a két csoport tekintetében. A divatvilágban dolgozók tizede, míg a nem a divatvilágban dolgozók egyharmada költ ennyit egy hónapban ruházkodásra. 


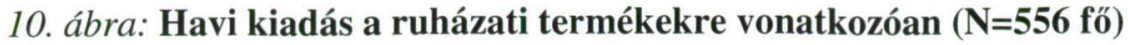

Nem divat világban dolgozók

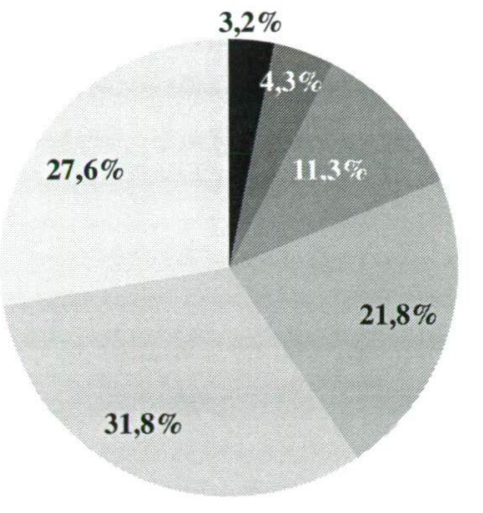

Divat világban dolgozók

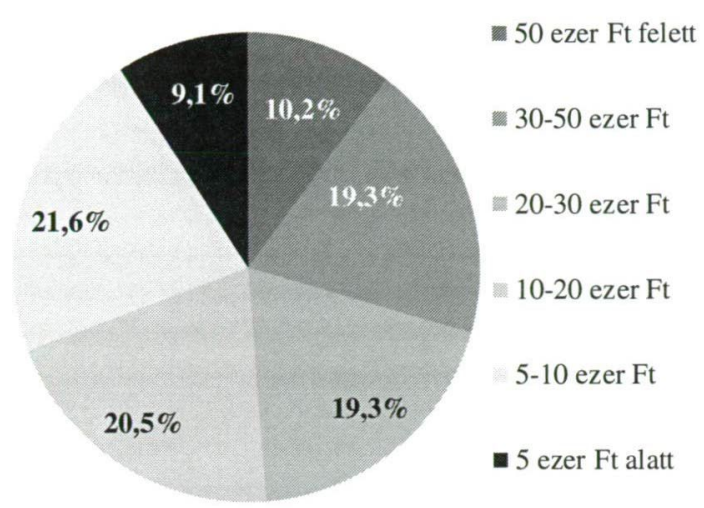

Forrás: Saját forrás (2017)

Elmondható tehát, hogy a nem divatvilágban dolgozók kevesebbszer járnak vásárolni és kevesebbet költenek ruházkodásra, míg a divatvilágban dolgozók többször mennek el vásárolni és ekkor többet költenek el egy adott termékre. Ez abból ered, hogy aki a divatvilágban dolgozik jobban oda kell figyelnie öltözködésére, a márkák szerepe nagyon fontos ebben a világban. Itt úgymond a márka teszi az embert azzá, aki. Míg a hétköznapi ember számára, aki nem a divatvilágban dolgozik nem annyira fontos az, hogy drága, márkás ruhát hordjon.

Ezen kérdésnél fontosnak tartottuk megvizsgálni, hogy a nök és a férfiak között van-e számszerüsíthető különbség. Anyagunkban a férfiak esetét mutatjuk be, mivel itt találtunk érdekes, meglepő válaszokat (11. ábra). A divatvilágban dolgozó férfiak 10000 forint alatt nem költenek havonta ruhavásárlásra. 10001-20000 forint között is kevesen, csupán 7,1\%-uk ad erre. A 20001-30000 és az 50000 forint feletti kategóriát a divatvilágban dolgozó férfiak közel 30\%-30\%-a válaszolta. A legtöbb beérkezett válasz alapján megállapítható, hogy a divatvilágban dolgozó férfiak többsége, azaz több, mint harmada a 30001-50000 forint közötti sávban költ. A nem divatvilágban dolgozó férfiak havi költési sajátosságai viszont teljesen ellenkezően alakultak. Az adatokból kiderült, hogy a nem divatvilágban dolgozó férfiak többsége, azaz közel 40\%-a 5001-10000 forintos tartományban szán egy hónapban ruházkodásra. Harmaduk kevesebb, mint 5000 forintot és ötödük 10001-20000 forintot költ. Ahogy növekednek a meghatározott árkategóriák, úgy csökken a nem divatvilágban dolgozó férfiak aránya, tehát ők nem szeretnek mélyen a zsebükbe nyúlni. 20001-50000 forint és afeletti kategóriában a kitöltők száma elenyésző. 


\section{1. ábra: A divatvilágban és nem divatvilágban dolgozók havi vásárlási sajátosságai $(\mathrm{N}=\mathbf{5 8})$}

50 ezer Ft felett $₫ 30-50$ ezer $\mathrm{Ft}=20-30$ ezer $\mathrm{Ft}=10-20$ ezer $\mathrm{Ft}=5-10$ ezer $\mathrm{Ft} \equiv 5$ ezer $\mathrm{Ft}$ alatt

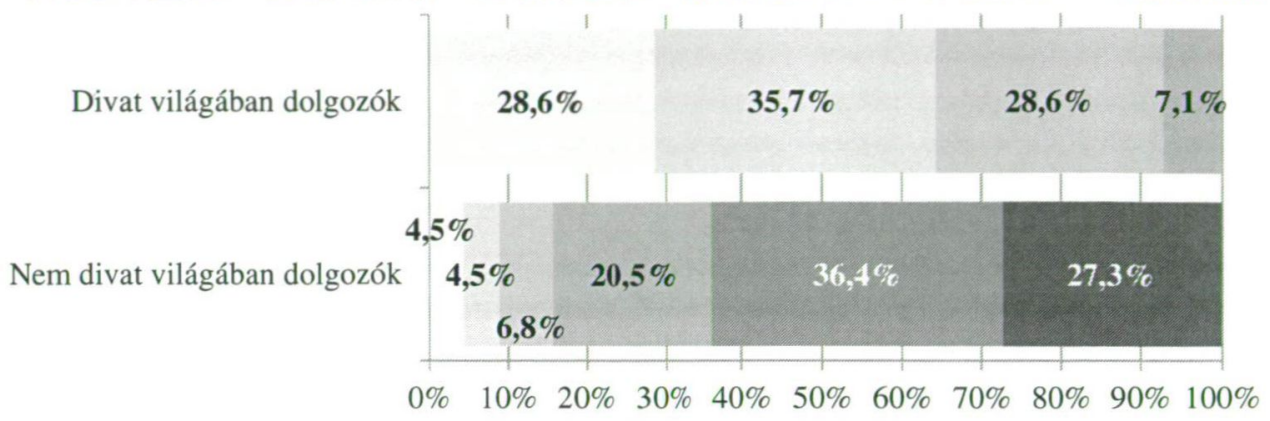

Forrás: Saját forrás (2017)

Megállapítható az a tény, hogy divatvilágban dolgozó férfiak többet költenek ruha vásárlására, mint nem divatvilágban dolgozó társaik. Ez az eredmény azért alakulhatott így, mivel az átlagos férfiak, akik nem a divatvilágban nem szeretnek gyakran ruhát vásárolni. Ök az üzletekben inkább a műszaki osztályon, illetve a szerszámok elött töltenek el több időt és ki is próbálják azokat. A ruhanemüket azonban már sokkal gyorsabban szerzik be, célirányosan végigszaladnak az osztályokon, amit elterveztek azt fogják megvenni. Ha nincs az adott termékből, amit a vásárlás előtt elterveztek, hogy meg fognak venni, akkor simán hátat fordítanak és haza mennek üres kézzel. Ezzel szemben a divatvilágban dolgozó férfiaknak nagy hangsúlyt kell fektetniük mindennapi öltözködésükre, több ruhával kell rendelkezniük, mint egy átlagos férfinak. Úgymond egy szettet, csak egyszer viselhet egy adott eseményen. Míg a divatvilágban dolgozó férfiak számára fontos, hogy márkás ruhákat viseljenek, addig a nem divatvilágában dolgozó férfiak nem tartják ezeket lényegesnek.

\subsection{A vásárlást befolyásoló tényezők és márkaismeret}

Ebben a részben fogjuk bemutatni az általunk vizsgált két csoportra vonatkozó vásárlást befolyásoló tényezőket, illetve azt, hogy mennyire ismerik az általunk megkérdezett márkákat. Kérdőívünk összeállítása során arra törekedtünk, hogy az olcsóbb árkategóriától a drágább kategóriáig vizsgáljuk meg a divatvilágban dolgozók és nem divatvilágban dolgozók elképzeléseit az általunk felsorolt márkákkal kapcsolatban. Ezeket úgy alakítottuk ki, hogy a ruházati piac szegmensei közül mind megtalálható legyen benne. Azért választottuk ezeket a márkákat, mert ezekkel jól lehet az adott csoportot szemléltetni.

Az egyi kérdésében azt vártuk az egyénektől, hogy értékeljék 1-től 5-ig terjedő skálán, hogy egy ruhadarab vásárlásakor mennyire befolyásolják őket a következő tényezők: az ár, a minőség, a márkanév, az egyediség, a reklámok, illetve a mások véleménye. Az ár és a minőség válaszait kielemezve szinte megegyező adatokat kaptunk mindkét általunk vizsgált csoport tekintetében. Eszerint megállapítható, 
hogy mindkét tényező nagyban szabályozza az egyének ruhavásárlási szokásait. A márkanév vizsgálata során leszögezhető, hogy a divatvilágban dolgozók vásárlására nagy hatással van a márkák szerepe, míg a nem divatvilágban dolgozók számára nem fontos az, hogy márkás ruhákat viseljenek. A reklámok és a mások véleményének befolyásolásának vizsgálata során születtek a legmeglepőbb eredmények. Ebből kiderült, hogy egyik csoportra sincsenek hatással a reklámok, illetve nem adnak mások véleményére. Ebben a kérdésben a legnagyobb eltérést az egyediség válaszainak vizsgálata mutatta. A divatvilágban dolgozók 75\%-a adott 4 és 5 pontot, míg aki nem a divatban tevékenykedik csupán fele törekszik arra, hogy egyedi legyen. Ez az eltérés abból is adódhat, hogy a divatvilágban dolgozóknak nagyobb hangsúlyt kell fektetniük külsejükre, mivel divateseményen való részvételnél a legfontosabb az, hogy valaki egyedi legyen.

A másik kérdésben arra voltunk kíváncsi, hogy az alanyok mennyire ismerik az általunk választott és megkérdezett márkákat, melyek a ruházati piac szegmenseit alapul véve választottuk ki (12. ábra). A felmérésböl az derült ki, hogy a H\&M-et és a ZARA-t és a Dolce \& Gabbana-t mindkét csoport ismeri és vannak köztük olyanok is, akiknek ez a kedvence is egyben. A divatvilágban dolgozók és a nem divatvilágban dolgozók között nagy eltérés tapasztalható a COS vizsgálata során. A COS a H\&M Group egyik prémium minőségü ruhákat árusító márkája, amely Magyarországon jelenleg egy budapesti üzlettel rendelkezik. A divatvilágban dolgozók ötöde, míg nem a divatvilágban dolgozók, több mint $60 \%$-a nem ismeri ezt a márkát. A Givenchy-t és az Alexander Wang-et a divatvilágban dolgozók majdnem 90-90\%-a ismeri, és itt az is észrevehető, hogy több egyén is a kedvencének jelölte öket. Míg a nem divatvilágban dolgozók közel 70-70\%-a vallotta úgy, hogy hallott már ezekről a márkákról.

A másik szembetünő nagy eltérés a Vetements márka kapcsán észlelhető. Ez a francia brand elég új, 2009-ben alapították. Ezért sem meglepö, hogy a nem divatvilágban dolgozók, több mint $70 \%$-a nem hallott még róla. Ezzel ellentétben a divatvilágban dolgozók $40 \%$-a nem ismeri a Vetements-et. A legmeglepőbb eltérést az utolsó márka, azaz a Supreme felmérésének eredményei hozták. Azt gondolhattuk volna, hogy ezt többségben a divatvilágban dolgozók ismerik, azonban a válaszokból kiderült ennek az ellentettje. Az értékelés után kiderült, hogy a divatvilágban dolgozók mindössze $80 \%$-a, míg a nem divatvilágban dolgozók $100 \%$ ismeri, hallott már a márkáról.

$\mathrm{Az}$ eredmények alapján meglepődtünk, mivel a divatvilágban dolgozók válaszainak kiértékelése során nem derült ki, hogy mi a kedvenc márkájuk a felsoroltak közül. Ez abból adódhat, hogy a divat folyamatosan változik, így vele együtt a divatvilágban dolgozó emberek ízlése is és nem alakul ki bennük egy olyan márka, ami a kedvencük lehet. 
12. ábra: A divatvilágban dolgozók (A) és nem a divatvilágban (B) dolgozók márkaismerete $(\mathrm{N}=556$ fö)

\begin{tabular}{|c|c|c|c|c|c|c|c|c|c|c|c|}
\hline (A) & & Ismeri & & & Nem isn & meri & & & Kedvenc & & \\
\hline Supreme & & & & 69 & $32 \%$ & & & & $22,73 \%$ & & \\
\hline Vetements & & & & $4,54 \%$ & & & & 38, & $4 \%$ & & \\
\hline Alexander Wang & & & & & 86,36 & & & & & & \\
\hline Givenchy & & & & & 87,50 & & & & & & \\
\hline Dolce \& Gabbana & & & & & 92,0 & $05 \%$ & & & & & $5 \%$ \\
\hline COS & & & & & $75 \%$ & & & & 19,3 & $32 \%$ & \\
\hline ZARA & & & & & $79,55 \%$ & & & & & $0,45 \%$ & \\
\hline $\mathrm{H} \& \mathrm{M}$ & & & & & 88,64 & $4 \%$ & & & & 11,3 & $36 \%$ \\
\hline & $0 \%$ & & $20 \%$ & & $40 \%$ & & $60 \%$ & & $80 \%$ & & $100 \%$ \\
\hline (B) & & Ismeri & & & Nem isme & neri & & & Kedven & & \\
\hline Supreme & & & & $5,55 \%$ & & & & & $45 \%$ & & \\
\hline Vetements & & 28,00 & & & & & 71,79 & & & & \\
\hline Alexander Wang & & & & 68,8 & $0 \%$ & & & & 31,2 & $0 \%$ & \\
\hline Givency & & & & &, $72 \%$ & & & & 26, &, $07 \%$ & \\
\hline Dolce \& Gabbana & & & & & &, $51 \%$ & & & & & 1 \\
\hline $\mathrm{cos}$ & & & $6,97 \%$ & & & & & $60 \%$ & & & \\
\hline ZARA & & & & & $87,39^{\circ}$ & & & & & 11,3 & $3 \%$ \\
\hline $\mathrm{H} \& \mathrm{M}$ & & & & & $7,35 \%$ & & & & & $22,22 \%$ & \\
\hline & $0 \%$ & $10 \%$ & $20 \%$ & $30 \%$ & $40 \%$ & $50 \%$ & $60 \%$ & $70 \%$ & $80 \%$ & $90 \%$ & $100 \%$ \\
\hline & & & For & rás: Saj & ját forrás & $s(201$ & & & & & \\
\hline
\end{tabular}

A következő kérdésünk vizsgálata során arra voltunk kíváncsi, hogy a felsorolt márkákról mit gondolnak a kitöltők, mi jut eszükbe elöször, ha meghallják a feltett állításokat. A szempontok a következők voltak: divat, minőség, kényelem, egyediség, alacsony ár, megfizethetetlen, extravagáns, fiatalos és elegáns. A ,divat” szó hallatán meglepő módon a divatvilágban dolgozók és nem a divatvilágban is többségében úgy vélekedtek, hogy a ZARA a legdivatosabb a felsoroltak közül. Ez meglepő számunkra, mivel nem gondoltuk volna, hogy a divatvilágban dolgozóknak ez lenne az álláspontjuk. Amire számítottunk volna az az Alexander Wang, de ezt csupán a divatvilágban dolgozók ötöde válaszolta. Minőség szempontjából a divatvilágban dolgozók a Givenchyről, a nem divatvilágban dolgozók pedig a Dolce \& Gabbanaról gondolják azt, hogy ezek rendelkeznek a legminőségibb termékkínálattal. A kényelem szempontjából megegyezik a két tábor nézőpontja. Mindkét csoport jelentős többsége a $\mathrm{H} \& \mathrm{M}$ válaszlehetőséget jelölte be. $\mathrm{Az}$ egyediség kérdése kapcsán a divatvilágban dolgozók az Alexander Wanget, míg a nem divatvilágban dolgozók a Dolce \& Gabbanat ikszelték be. A következő 
szempont vizsgálata során mindkét csoport közel 100\%-100\% válaszolta ugyan azt. Úgy gondolják, hogy a felsorolt márkák közül a H\&M rendelkezik a legalacsonyabb árakkal. Ez nem meglepő, hisz a megkérdezett márkák kiválasztásakor figyeltem arra, hogy a legolcsóbbtól a legdrágábbig szerepeljenek a kínálatban, illetve, hogy minden ruházati piaci szegmens képviseltesse magát. A divatvilágban dolgozók és nem a divatvilágban dolgozók is hasonlóan vélekednek a következő állítás kapcsán. Úgy vélik, hogy a legdrágább a Dolce \& Gabbana, szerintük ez a márka megfizethetetlen kategória.

Azt, hogy melyik a legextravagánsabb a felsoroltak közül azt a választ kaptuk, hogy a divatvilágban dolgozók szerint az Alexanger Wang, míg a nem divatvilágban dolgozók közül a Dolce \& Gabbanat.

Utolsó előtti perspektíva a fiatalosság volt. A divatvilágban dolgozók szerint az Alexander Wang a legfiatalosabb márka a felsoroltak közül. A nem divatvilágban dolgozók úgy vélekedtek, hogy a H\&M-et jelölik e szempont vizsgálata során. Arról, hogy mit gondolnak a kitöltők, melyik a legelegánsabb márka a két csoport válaszai eltérnek. Megállapítottuk, hogy a divatvilágban dolgozók többsége szerint a Dolce \& Gabbana, míg a nem divatvilágában dolgozók szerint a ZARA a legelegánsabb márka. A felsorolt szempontok között a legnagyobb eltérés a divatvilágban és nem divatvilágban dolgozók között a fiatalos jelző vizsgálata során volt tapasztalható (13. ábra).

\section{3. ábra: A divatvilágban dolgozók és nem divatvilágban dolgozók fiatalos jelző iránti megoszlása a felsorolt márkák tekintetében $(\mathbf{N}=556$ fö)}

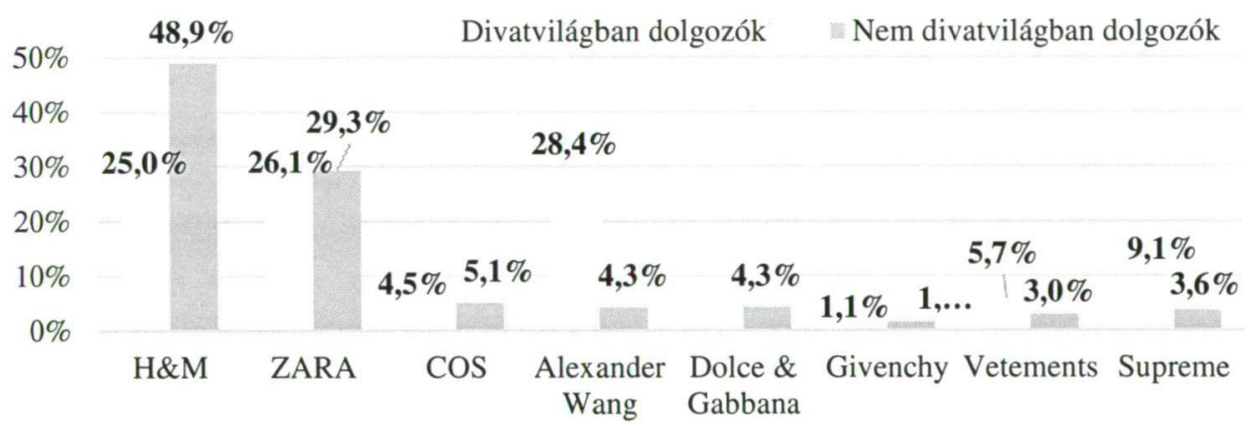

Forrás: Saját forrás (2017)

Tehát levonható az a következtetés, hogy a divatvilágban dolgozók és nem divatvilágban dolgozók ízlésvilága között nincs akkora nagy különbség, mint azt gondoltam. Több állítás vizsgálata során is majdnem azonos számban válaszoltak a feltett állításokra. Az viszont nagy meglepetés volt számunkra, hogy a divatvilágban dolgozók többsége a ZARA-t választotta a „divat” szó hallatán. Inkább a többi, felsőbb kategóriás divatházakat vártam válaszul, mint például az Alexander Wang, a Dolce \& Gabbana vagy a Givenchy. Továbbá meglepetésként ért az is, hogy a divatvilágban dolgozók közül szinte alig választotta valaki a Vetements vagy Supreme márkákat. 
Az utolsó vizsgálati szempont az volt, hogy a divatvilágban dolgozók és nem a divatvilágban dolgozók mennyire tartják magukat divatosnak, mennyire öltözködnek a mai trendeknek megfelelöen.

Az ide vonatkozó kérdés skálás kérdés volt, ahol állításokat fogalmaztunk meg, ami alapján a válaszadóknak 1-től 4-ig terjedő skálán kellett eldönteniük, hogy mennyire értenek egyet azokkal. Az 1. skála azt jelentette, hogy egyáltalán nem értek egyet, a 4. pedig a teljesen egyetértek funkciót jelölte. Az állítások a következők voltak: szeretek divatosan öltözködni; szeretek ruhákat, kiegészítőket vásárolni; követem a divatot; diktálom a divatot; számomra fontos, hogy különleges, egyedi ruhákat viseljek. A divatvilágban dolgozók közel 85\% értett azzal egyet, hogy szeret divatosan öltözködni, viszont a nem divatvilágban dolgozók csupán $70 \%$ vallotta ugyan ezt magáról. A szeretek ruhákat, illetve kiegészítőket vásárolni állításunkra a divatvilágban dolgozók 90 százalékuk, míg a nem divatvilágban dolgozók 75\%-a értett egyet ezzel a kijelentéssel. Elmondható, hogy a divatvilágban dolgozók közel $60 \%$-a, míg a nem divatvilágban dolgozók $40 \%$-a követi a divatot. A válaszok közti legnagyobb eltérést annál a kérdésnél tapasztaltunk, amikor arra voltunk kíváncsiak, hogy a válaszadók mennyire diktálják a divatot. A divatvilágban dolgozók 45\%-a vallotta úgy, hogy diktálja a divatot, míg a nem divatvilágban dolgozók csupán tizede válaszolt így erre az állításunkra. Ez nem meglepő, hiszen pont a nem divatvilágban dolgozók azok, akik inkább követik a divatot, minthogy diktálják azt. Utolsó állításom arra irányult, hogy mennyire fontos a kitöltőknek, hogy egyedi ruhákat viseljenek. Ez alapján kiderült, hogy a divatvilágban dolgozók 70\%-ának, míg a nem divatvilágban dolgozók 40\%-ának fontos az, hogy divatos, egyedi ruhákat hordjanak. Megállapítható tehát, hogy a divatvilágban dolgozók majdnem 85\%-a vallja magát divatosnak, míg a nem divatvilágban dolgozók 67,5\%-a választotta azt a lehetőséget, hogy divatos, a mai trendeknek megfelelöen öltözködik (14. ábra).

\section{4. ábra: A divatvilágban és nem divatvilágban dolgozók divatosságának vizsgálata $(\mathbf{N}=556$ fö)}

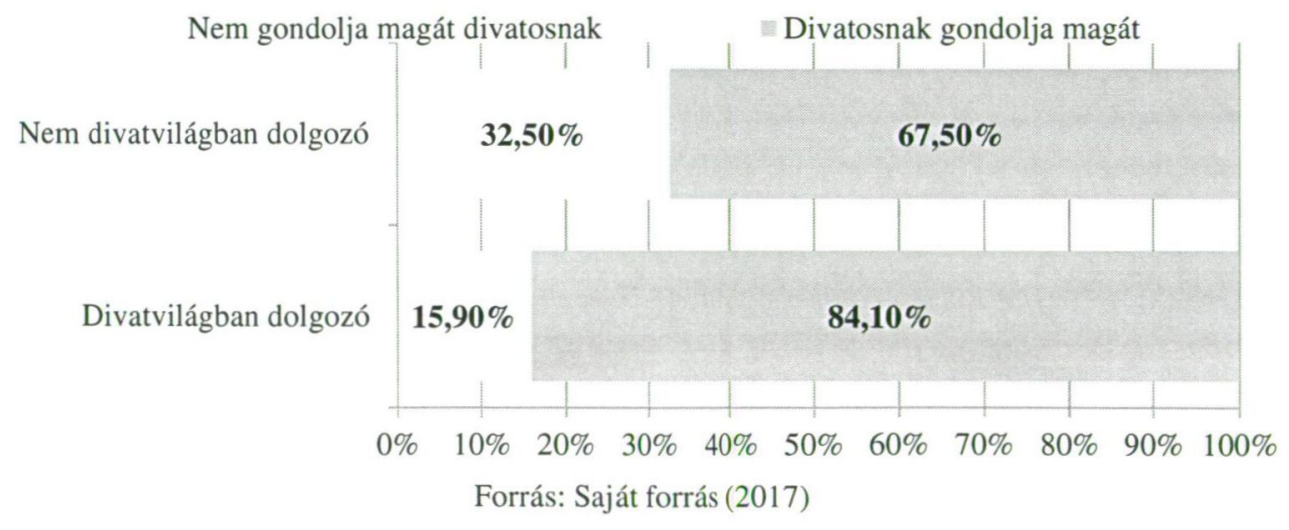




\section{Következtetések és javaslatok}

$\mathrm{Az}$ eredményeket összegezve elmondható, hogy a divatvilágban és nem divatvilágban dolgozók vásárlási szokásaik eltérnek, viszont a két csoport között nem akkora nagy az eltérés, amire számítottam. A kiértékelés után kiderült, hogy a divatvilágban dolgozók többsége, közel $40 \%$-uk havonta többször, illetve hetente harmaduk vásárol magának ruhákat, kiegészítőket. Ezzel ellentétben a nem divatvilágban dolgozók azt a tendenciát mutatják, hogy ők csak havonta, vagy annál ritkábban, szezonálisan szerzik be ruhadarabjaikat.

A megkérdezettek mindkét csoportjáról kiderült, hogy azonos időt szánnak ruhavásárlásra. Ez annak köszönhető, hogy a mai rohanó világban egyre kevesebb idejük van az embereknek időt szánni ezekre a dolgokra. Viszont az meglepő volt számomra, hogy a divatvilágban dolgozók is a 31-60 perces intervallumban vásárolnak.

Levonható az a következtetés, hogy a divatvilágban dolgozók többször mennek el vásárolni és ekkor többet költenek el ruházkodásra, míg a nem divatvilágban dolgozók kevesebbszer járnak vásárolni és kevesebbet költenek el egy adott termékre. Ez abból ered, hogy aki a divatvilágban dolgozik jobban oda kell figyelnie öltözködésére, a márkák szerepe nagyon fontos ebben a világban. Itt úgymond a márka teszi az embert azzá, aki. Míg a hétköznapi ember számára, aki nem a divatvilágban dolgozik nem annyira fontos az, hogy drága, márkás ruhát hordjon.

\section{Irodalomjegyzék}

Agárdi I. (2010): Kereskedelmi marketing és menedzsment. Akadémia Kiadó, Budapest.

Bauer A., Berács J., Kenesi Zs. (2007): Marketing alapismeretek. Aula Kiadó, Budapest.

Business Insider (2015): In: Gould S., DeBord M. (2015): The world's top 10 fashion brands are worth $\$ 122$ billion <http://www.businessinsider.com/the-worlds-top-10-fashion-brands-areworth-122-billion-2015-7> (2017.09.28.)

Fazekas I., Harsányi D. (2011): Marketingkommunikáció érthetõen. Szókratész Külgazdasági Akadémia, Budapest.

Kovács K. (2009): A divattermékek fogyasztása és a divatterjedés racionális és emocionális mozgatói. Akadémia Kiadó, Budapest.

KSH (2016): Statisztikai tükör - A háztartások fogyasztása, 2016. I. félév <http://www.ksh.hu/docs/hun/xftp/stattukor/haztfogy/haztfogyl606.pdf> (2017.02.12.)

Kybalová, L., Herbenová, O., Lamarová, M. (1974): Képes divattörténet az ókortól napjainkig. Corvina Kiadó, Budapest.

Majoros P. (2004): A kutatásmódszertan alapjai. Perfekt Zrt., Budapest.

Martin, J., Lehu, A. P. (2011): Öltözködés. Panem Kiado, Budapest.

Molnár T. (2017): Stílus és divat <http://stilusmentor.hu/stilus-es-divat/> (2017.10.17.)

Olins, W. (2004): A márkák - a márkák világa, a világ márkái. Jószöveg Mühely, Budapest.

Rédey P. (1990): Hétköznapi marketing - tanácsok, trükkök, tippek. Intertrade Kft., Budapest.

Rekettye G., Töröcsik M., Hetesi E. (2015): Bevezetés a marketingbe. Akadémia Kiadó, Budapest.

Vágási M. (2007): Marketing - stratégia és menedzsment. Aline Kiadó, Budapest. 